NBER WORKING PAPERS SERIES

HOST COUNTRY BENEFITS OF FOREIGN INVESTMENT

Magnus Blomstrơm

Working Paper No. 3615

NATIONAL BUREAU OF ECONOMIC RESEARCH

1050 Massachusetts Avenue

Cambridge, MA 02138

February 1991

This paper is part of NBER's research program in International Studies. Any opinions expressed are those of the author and not those of the National Bureau of Economic Research. 
NBER Working Paper \#3615

February 1991

\title{
HOST COUNTRY BENEFITS OF EOREIGN INVESTMENT
}

\section{ABSTRACT}

This paper reviews the empirical evidence on the very different conclusions that can be drawn about productivity spillovers of foreign direct investment. It explains the concept of host country spillover benefits, describes the various forms these benefits can take, both within and between industries, and summarizes the evidence regarding the relative magnitudes of the various forms of spillovers. Moreover, the paper discusses host country policy measures which can accelerate both the MNC affiliates' technology imports and the diffusion of their technology in the host economies.

\author{
Magrus Blomstrōm \\ Stockholm School of Economics \\ P.O. Box 6501 \\ 11383 Stockholm, SWEDEN
}


HOST COUNTRY BENEFITS OF FOREIGN INVESTMENT*

Magnus Blomström

\section{Introduction}

The possibility of getting access to modern technology is perhaps the most important reason why countries wish to attract foreign investment. By inviting multinational corporations (MNCs), host countries may get access to technologies that they cannot produce by themselves. Foreign direct investment can also lead to indirect productivity gains for host country firms through the realization of external economies. Generally these benefits are referred to as "spillovers", which indicates the importance of the way in which the influence is transmitted.

There are several ways in which technology spillovers may occur. Multinational firms may, for instance, increase the degree of competition in host-country markets and in that way force existing inefficient firms to make themselves more productive by investing in physical or human capital. MNCs may also provide training of labor and management which may then become available to the economy in general. Another possible channel for spillovers is the training of local suppliers of

\footnotetext{
* I am grateful to Ari Kokko, Robert Lipsey, and Don McFetridge for comments on an earlier draft of this paper, and to Investment Canada for financial support.
} 
intermediate products to meet the higher standards of quality control, reliability, and speed of delivery required by the technology and method of operation of the foreign-owned company. The purpose of this paper is to discuss the very different conclusions that can be drawn about productivity spillovers from foreign investment. Since the technology transferred abroad by multinationals constitutes the potential for spillovers to local firms, the paper begins by considering MNCs as carriers of technology and examining the determinants of their technology transfer activities. Second, it explains the concept of host country spillover benefits, describes the various forms these benefits can take, both within and between industries, and summarizes the evidence regarding the relative magnitudes of the various forms of spillovers. Third, the paper discusses host country policy measures which can accelerate both the MNC affiliates' technology imports and the diffusion of their technology in the host economies. Finally, section 5 summarizes and concludes the paper.

\section{International Technology Transfer and the MNC}

The attention given to the role of multinationals in the international transfers of technology is not surprising, for at least two reasons. First, multinational corporations undertake a major part of the world's research and development efforts and produce, own, and control most of the advanced production 
3

technology. R\&D is crucial for MNCs, since such efforts create ownership-specific advantages that enables firms to operate in foreign countries (see e.g. Caves, 1982). Secondly, MNCs and their host countries can often be expected to have different objectives with respect to technology transfers. The technology recipients are interested in obtaining technology at as low a price as possible. The MNCs, on the other hand, have to protect their intangible assets and other similar advantages needed to make foreign investment possible.

The characteristics of the technology brought overseas by multinationals seem to depend on a number of factors, one of them being the form of engagement by the multinationals. Evidence confirms that the more modern and complex the technology, the less willing the multinationals are to accept any arrangements other than wholly owned subsidiaries, in order to avoid leakages. For example, Mansfield and Romeo (1980) found that technologies transferred to affiliates were of a later vintage than those sold to outsiders. The average age of a sample of technologies at the time of their first transfer to subsidiaries in developed countries was 5.8 years (and that for developing countries was 9.8 years), whereas the corresponding figure for outside 1 icensing and joint ventures was 13.1 years. Results reported for Canada by McFetridge (1987) are consistent with these findings. His results confirmed that the type of technology influences the mode of transfer and that transfer lags 
tend to be shorter for intra-firm (internal) transfers than for other transfer types.

Also Behrman and Wallender (1976), in a detailed study of several cases of technology transfers, emphasized the qualitative differences between technology transfers within multinationals and transactions between independent parties. More advanced technologies were transferred on an intra-firm basis. They also stressed the continuous character of intra-firm technology flows and identified five general mechanisms of technology transfers, that are more or less intensively used throughout an affiliates entire lifetime, namely:

- documentation, in the form of manuals and technical publications,

- instruction, education, and training of employees,

- visits and exchanges of technical personnel,

- development and transfer of specialized equipment, and

- trouble shooting, i.e. continuing oral and written communication to solve problems.

Furthermore, various characteristics of the transferors seem to influence the costs of technology transfer and, thus, the type of technology brought overseas by multinationals. For instance, Teece (1976) demonstrated learning by doing in international technology transfers, in the sense that the transfer costs decreased with the number of transfers. Moreover, 
Davidson (1980) suggested that transfer costs declined as firms became more familiar with international operations in general, and with their individual markets in particular (see also Blomström and zejan, 1991). Thus, a firm's experience in foreign operations is likely to speed up the technology transfer process to affiliates, other thing being equal.

Host country characteristics also influence the level of technology exports. To a large extent, the host country's technological capability, for example in terms of a well educated work force, determines what sort of technology is possible to transfer. As Teece (1976) finds, the cost of transferring specific technologies decreases with increasing capabilities in the host economies; Behrman and wallender (1976) and Cortes and Bocock (1984) provide illustrative examples for certain industries. Kokko (1990), in a study of technology imports by U.S. affiliates in 32 countries, also concludes that the amount of technology transferred increases with the host country's technological capability (see also Mansfield and Romeo, 1980, Chen, 1983, and Dahlman, et a1., 1987). Thus, it seems safe to conclude that more technology is transferred, the more advanced the recipient country or firm.

The willingness of multinationals to bring technology is also influenced by host country policies. Many countries apply various technology transfer requirements, that typically mean that MNCs are forced to employ a minimum of local labor, make 
technologies available for local firms, restrict imports, or use local suppliers. These requirements increase the cost of certain types of technology transfer and should, therefore, depress the affiliates' technology imports. (See e.g. McFetridge, 1987 and Grosse, 1989 for evidence).

\section{Foreign Investment and Spillovers}

It might be argued that the MNC affiliates' technology imports lead only to a geographical diffusion of technology, but not to transfers to new users, because the ownership and control of technologies are largely kept in the MNCs' possession. However, since technology to some extent is a public good, foreign investment can also result in indirect gains for host countries through the realization of external economies or spillovers. In what follows, we shall discuss both the influence of foreign firms on the efficiency of their host country competitors ("intra-industry spillovers") and the influence of foreign firms on their local suppliers and customers ("inter-industry spillovers") .

\section{Intra-industry spillovers}

There are several ways in which intra-industry spillovers may occure. One potential channel is competition. Although multinationals may suffer from some disadvantages vis-à-vis the domestic entrants - for example, as far as knowledge of consumer 
and factor markets and the favor of local governments are concerned - it is likely that they enjoy other and more important advantages in overcoming barriers to entry such as capital requirements, risks, and research and development intensity. We therefore expect MNCs to have better possibilities to enter markets where barriers to entry for new firms are high (see Gorecki, 1976, for affirmative evidence), and that foreign entry may increase competition in host-country markets and force inefficient domestic firms to adopt more efficient methods. Existing inefficient local firms may be forced by the competition of foreigners to make themselves more productive by investing in physical or human capital, or simply by paying more attention to possibilities for raising productivity. Moreover, the least efficient local firms may be driven out of business, freeing the resources they had controlled to more productive companies.

Another source of gain to the host economy is the training of labor and management which takes place in the multinationals and may then become available to the economy in general. The local employees who are trained in the multinationals may find it advantageous to exploit the human capital thus acquired by moving to locally-owned firms or by becoming entrepreneurs on their own. An employee trained and educated or experienced at a certain level by a multinational corporation may add much more to the profitability of a locally-owned firm, with no such employees, than to that of the multinational that provided the training, 
because in the foreign-owned firm, the trained employee is only one of a large number of similar employees. Since manegerial talent, scientists, and skilled workers are in short supply in developing countries, we expect this type of spillover efficiency to be more important there than in developed countries.

A third possible source of intra-industry spillover efficiency benefits is that MNCs may speed up the transfer of technology. For both process and product technology, such a transfer is a central activity of MNCs, and this may stimulate domestic firms to hasten their access to a specific technology, because they would not otherwise have been aware of the technology's existence, or they would not have felt it profitable to try to obtain the technology.

Several of the early studies of foreign investment provided anecdotal evidence on indirect productivity gains for host countries from the presence of multinationals (see e.g. Dunning, 1958, Brash, 1966, Safarian, 1966, and Deane, 1970). More direct (although rough) tests of foreign investment and spillovers have been undertaken in a study for Australia by Caves (1974), for Canada by Globerman (1979), for Hong Kong by chen (1983), and for Mexico by Blomström and Persson (1983) and Blomström (1989). Although none of these studies was able to analyze the nature of spillover efficiency in any depth, they all found evidence to support the spillover benefit hypothesis. Productivity levels of domestic firms increased with the foreign subsidiaries' share of 
the market.

The existence of leakage of technology from multinationals to host country competitors was also confirmed by Mansfield and Romeo (1980) in a detailed study of technology exports by U.S. firms (see also Mansfield, 1982). They found that the introduction of MNC technology abroad speeded up the appearance of competing products or process by at least 2.5 years in about one-third of their cases. Moreover, they used information from a sample of British firms to examine whether these had been affected by technology transfers by U.S.-based firms to their U.K. subsidiaries. Over half of them believed that at least some of their products and processes had been introduced, or introduced more quickly, because of the transfer of new products or processes by U.S. multinationals.

Also Blomström and Wolff (1989), in a study of Mexican manufacturing industries, found that there were notable productivity spillovers within industries. Furthermore, they tried to measure the size of these spillovers by asking if they were large enough to generate international productivity catchup. They found strong evidence that the presence of multinationals acted as a catalyst to the productivity growth in Mexico and that foreign direct investment speeded up the productivity convergence process between Mexico and the United states.

There is also some evidence available regarding the 
relationship between spillover efficiency benefits and industrial and national characteristics. A recent study by cantwell (1989) analyzes the impact of U.S. investment in Europe on the competitiveness of European industries and firms, and he finds that the effects vary strongly between countries and industries. According to him, countries are likely to enjoy spillovers only in the areas in which their firms have been successful in the past. Hence, the competitive stimulus of the entry of U.S. firms into Europe helped to spur an indigenous revival in areas of traditional technological strengthl.

Also Blomström (1986), in a study of the effects of foreign investment on the productive efficiency of the industrial structure in Mexico, pointed to the competitive stimulus of multinational participation as an important channel for spillovers. In fact, his findings suggested that the competitive pressure induced by the foreign firms was the most important source of spillover efficiency. Although there is no other statistical investigation to support this conclusion, there is a lot of indirect support for it in the literature. A number of studies have confirmed that the rate of entry of multinationals is negatively related to the changes in market concentration (see e.g. Rosenbluth, 1970, Dunning, 1974, and Knickerbocker, 1976). Thus, it seems that foreign investment tends to reduce the level of concentration and increase competition in host country industries, which in turn may promote greater efficiency in 
domestic firms.

The available evidence on spillovers from the training of employees by multinationals is more sketchy and comes mainly from developing countries. Katz (1987) points out that many manegerial people in locally owned firms in Latin America started their careers in foreign companies and claims that the host countries have recieved important spillovers in this way: $A$ study of recent development in Southeast Asia by Yoshihara (1988) suggests the importance to chinese-owned firms of both training in foreign companies and education in foreign schools; Gerschenberg (1987), using career data from 72 top and middle level managers employed in 41 firms in Kenya, concludes that multinationals have played an important role in the dissemination of managerial know-how in that country; wasow (in shelp et al., 1984) describes the loss of trained employees to other firms as one of the main ways in which insurance industry technology is transferred outside the company he studied (AIG). For instance, "in the Philippines, AIG is known as the 'training ground' for the insurance industry" (p. 45); Behrman and wallender (1976) find not only that managers trained by multinationals move on to join other firms, but also that multinational companies transfer management technology through assistance to their local suppliers. (see also Gabriel, 1967, Balasubramanyam, 1973, Lall, 1980, Buckley and Artisien, 1987, and Lipsey, 1990). Thus, the available evidence from developing countries seems to suggest 
that there exist spillovers from the training of employees by multinationals. Although MNCs may have smaller training effects in developed countries, they may still have an incubator effect (i.e. incubating new spin-off local business), but to the best of my knowledge, there is no evidence regarding multinationals as incubators.

Even if technology leaks out from multinationals to host country firms, it is worth pointing out that such leakages do not occur automatically, but require major investment by the recipient. The learning of technology to the point of mastery is an active process. Searching for information, reverse engineering, personnel training for the new production methods, et cetera, make learning costly and time consuming. Thus, it is via the investment mechanism that new technologies are diffused. I will come back to discuss this later.

\section{Inter-industry spillovers}

Another potential source of spillover efficiency benefits is the impact made by the foreign subsidiaries on their local suppliers and customers. The new technology brought in by multinationals may stimulate local suppliers of intermediate products to improve product quality and lower cost in order to compete for the MNC market. New products introduced by the foreign firms may also stimulate productivity improvements in local firms purchasing these products. 
Systematic analyses of the effects of foreign participation on industries outside their own are lacking, although this presumably is an important source of technology transfer. Some studies have shown that the local purchases of inputs tend to increase as the multinationals' subsidiaries mature (see e.g. Safarian, 1966, Forsyth, 1972, and McAleese and McDonald, 1978), but none of these investigations deal with spillover effects. A number of case studies, however, have touched on the spillover issue. In his study of American investment in Britan, Dunning (1958) found that foreign firms were generally engaged in the training of local suppliers and suggested that inter-industry spillovers were significant. Another suggestive study is that of Brash (1966), who discussed the impact made by General Motors in Australia on its local suppliers, by insisting that they meet standards of quality control. Lim and Pang (1982), who surveyed the electronic industry in singapore, found that multinationals were willing to assist in the establishment of local supplier firms, suggesting entrepreneurial possibilities, providing technical assistance, financial aid, managerial advice, guaranteed business, and marketing information. Also Reuber, et al. (1973), Behrman and Wallender (1976), Germidis (1977), and Lall (1980) provided some empirical evidence on spillover effects of foreign investment on industries outside their own, but nobody has followed up this line of research with statistical analyses ${ }^{2}$. Before drawing strong conclusions about inter-industry 
spillovers, more research is needed. However, the limited evidence still suggests that technology is leaking out also to the multinationals' suppliers and customers. Some recent developments also seem to suggest that this kind of spillovers might become more important in the future. Data show, for instance, that multinationals from sweden, to an increasing extent, are using independent subcontractors, both at home and abroad (see Eliasson, 1985), which would enlarge the potentials for "backward" spillovers.

Because of the rapid technological change that is currently taken place, I also believe that spillovers to the multinationals' customers in the host economies will become much more important in the future. The reason for this is that the newly emerging technologies, like microelectronics and the new generation of computer-based automation and information technologies, are generally so knowledge and research intensive, and expensive to develop, that only a few, large firms (MNCs) can afford such efforts. Small countries facing the technological revolution, thus, have to accept a certain degree of dependence on the MNCs' technology. For them, it is more important to have the capability to use advanced technologies than to produce them, something which is clearly shown in the history of the smaller European countries (see Blomström and Meller, 1991). Small countries should, therefore, put less emphasis on developing entirely new, cutting-edge technologies, than on promoting the 
widespread dissemination of technological capabilities throughout the economy.

In discussing these new technologies, it is essential to recognize that their main influence on the behaviour of the economic aggregates is indirect rather than direct. For example, while the computer industry by itself makes only slight contributions to the output and employment in the countries where production takes place, the computer has found applications everywhere. In all countries, computers are now used in every service, but they are also used in different functions within the enterprises (administration, production, design, marketing, and research). Thus, access to these new high-technology fields will become increasingly essential for firms to sustain competitiveness.

Moreover, it has been shown that whilst thresholds in some advanced technology areas are high for both $R \& D$ and investment, there are relatively low threshold costs in a number of software applications and in many specialized areas of instrumentation and machinery (OECD, 1989). This suggests that the recently emerging technologies open up many new possibilities and opportunities for small countries. The fact, for instance, that sweden today produces advanced technologies does not mean that it has become independent of foreign technology. On the contrary, sweden is more dependent on foreign technology today than ever before. For example, the Swedish success in high-tech areas, such as 
telecommunication equipment, is based partly on U.S. technology (see Blomström, Lipsey, and Ohlsson, 1989). Thus, by importing technology and high-tech components from the United states (and other countries), Swedish firms can stay competitive on world markets in various high-tech "niches".

This also suggests important implications for trade policies. Since technology has become so complex and expensive to develop, the access to foreign products and technology via imports has become more important than ever for firms in all countries, including the United states. Import restrictions may have devastating effects on economic growth, as shown, for example, by the recent experience of Brazil. In 1984, the Brazilian Congress overwhelmingly voted to reserve the market for micro- and mini-computers for national manufacturers for eight years. As a consequence, after six years of limited access. to the world computer revolution, the cost of Brazilian personal computers is generally twice that of their foreign equivalents on the international market; a facsimile machine costs seven times more (New York Times, July 9, 1990). This policy has now become too costly to retain and Brazil has therefore decided to do away with it.

\section{How to Influence the size of Spillovers}

What policy measures countries hosting multinationals should adopt to get these firms to transfer more technology, and 
in that way increase the potential for spillovers, have been widely discussed over the years. Generally it has been thought, that in order to increase benefits from an MNC project, governments have to use different types of proscriptions. Many countries have, therefore, started to frame the environment within which multinational firms operate and have introduced various performance requirements for their behavior. special attention has been given to policies regarding technology transfer, and a number of measures intended to encourage multinational firms to increase their technology transfer have been introduced over the years, including requirements for local content and local R\&D.

A different view on how to influence the potential and the size of spillovers has recently been suggested by Blomström and Wang (1989). They develop a model in which international technology transfer through foreign direct investment emerges as an endogenized equilibrium phenomenon, resulting from the strategic interaction between subsidiaries of multinational corporations and host country firms. Their model highlights the essential role played by competing host country firms in increasing the rate at which the multinationals transfer technology and suggests that countries hosting multinationals should concentrate on supporting their domestic firms in their efforts to learn from the foreigners, rather than stipulating performance requirements for the multinationals, if they want to 
increase the technology transfer from the multinationals. Empirical evidence from U.S. majority owned foreign affiliates in some 32 countries largely confirms this theoretical hypothesis (see kokko, 1990). His findings suggest that technology imports by MNC affiliates increase with the income level of the host country and (proxies for) the competitive pressure in the host economy, and decrease with the level of distortions and various host country performance requirements. The negative impact of different performance requirements on the multinationals' technology transfer activities is also confirmed in McFetridge (1987), while Lake (1979) demonstrates the positive effect of competition. In his study of the semi-conductor industry in the United states and the United Kingdom, he found that technology diffusion was faster the more competitive was the industry in which it occurred.

These findings have important policy implications. If the MNC affiliates actually adapt their behavior to local conditions - read local competition and supply of educated labor - then the set of instruments for the host countries' technology policy increases notably. Rather than relying on controls and direct supervision of MNCs to secure some benefits from their operations, local governments have the option to create an environment which fosters spillovers and continuing technology transfers. Supporting competition in the industry where a MNC enters, e.g. through subsidies to education and training in local 
firms (or by inviting another competing MNC) has dual benefits. Firstly, the MNC is forced to adjust to competition by upgrading its production processes and importing technology, in pace with the competitiors' productivity improvements. Secondly, the continuous inflow of technology increases the spillover potential, while the support to local firms increases the likelihood of actual spillovers. In other words, a 'virtuous circle' of productivity and technology growth is possible, in contrast to the 'vicious circle' that occurs when the MNC is allowed to operate without any competition, and risks to fall further and further behind the global standards.

Recently there has also been a lot of concern, both in home and host countries, over the multinationals' research and development activities. Home-country governments are mainly worried about the negative effects of R\&D investment overseas and emphasize the risk of facilitating, for actual or potential competitors, the access to technology on which the home country's competitive position relies (see Zejan, 1990). In the host countries, there is generally a positive attitude towards the development of R\&D activities in the foreign subsidiaries. Such activities are expected to contribute in different ways to local technological capability, and have come to be identified as vital to industrial competitiveness.

Research alone, however, does not guarantee that the economic benefits of research investment will be realized by the 
nation making the investment. As we have shown in several studies, the competitiveness of countries can behave very differently from that of the firms that are located there, if these firms produce abroad as well (see e.g. Lipsey and Kravis, 1985 and Blomström and Lipsey, 1989). National policies aimed at improving the competitiveness of a country may therefore fail, if they create or subsidize assets that improve the competitiveness of firms that can exploit these assets in other countries. Let me give one example.

The Swedish government has, for a long time, supported fims to undertake research and development in Sweden. And as can be seen from Figure 1, in the 1980s, Sweden became the OECD country with the highest ratio of business enterprise R\&D to industry output. The idea behind this policy is that an increase in research and development will upgrade the Swedish production over time and raise Sweden's competitiveness in high-tech products.

Insert Figure 1.

However, there is little impact from this policy, so far, if we look at the type of products Sweden is exporting. Dividing Swedish exports into three categories, high, medium, and low 
tech, it can seen (from Figure 2) that there has been no shift towards exports of high-tech products in sweden since 1970 . On the contrary, the big devaluation in 1982 increased the competitiveness of low-tech industries.

Insert Figure 2.

There are several possible explanations as to why swedish exports have not been shifting towards high-tech products, despite the increasing $R \& D$ activities in Swedish firms. One is that research and development is a long term investment and that the effects have yet not appeared in Swedish exports. If this is correct, a shift to high-tech export is to be expected. However, given that swedish firms have spent more on $R \& D$ as a per cent of value added than their main competitors since the mid-1970s, and even more than U.S. firms since the end of the 1970s, this explanation is not very likely.

A second possibility is that research and development has been misdirected in sweden, and that the output from it will never appear in the trade statistics. According to OECD (1986), there seems to be some truth in this explanation. In general, the OECD suggests that Swedish $R \& D$ is inefficient in generating the production and export of new products. 
Thirdly, it is argued that swedish R\&D has mainly been directed towards rationalizing techniques for the production of low-tech products, such as pulp and paper. This has certainly been the case, but the weighted impact of these improvements has not been large enough to prevent sweden from falling behind many of its competitors in terms of income per capita.

The fourth and final possibility is that swedish multinationals base their R\&D for the whole organization in Sweden, while carrying out a large chunk of high-tech production abroad. In other words, Swedish firms' R\&D efforts in Sweden might raise their competitiveness in high-tech products, but the firms do not find sweden the most suitable location for high-tech production. Since the results of R\&D are transferable across international borders within firms, Swedish multinationals might choose to do their high-tech exporting from other countries than Sweden. At least two observations support this explanation for why Swedish R\&D does not generate Swedish production and export of high-tech products. One is that more than 85 per cent of Swedish MNCS' R\&D is based in Sweden (Swedenborg, 1988). The other is that the competitiveness of Swedish multinationals, defined as their share of world or developed country exports, has increased since the mid-1960s, while that of Sweden has decreased (Blomström and Lipsey, 1989). 


\section{Concluding Remarks}

The particular concern of this paper has been to review the evidence on the very different conclusions that can be drawn about productivity spillovers of foreign direct investment. The general picture that emerges from the empirical spillover literature is that such effects exist, and that they may be quite substantial both within and between industries, but there is no strong evidence on their exact nature. Moreover, recent research suggests that spillovers vary between countries and industries and are likely to increase with the level of local capability and competition.

The perception of spillovers as endogenous phenomena complicates the discussion of what policy measures can accelerate the MNC affiliates' technology imports and the diffusion of their technology in the host economies. Evidence suggests that various technology transfer requirements may not always produce the intended results. At best, requirements may secure diffusion of a large share of a smaller technology stock; alternative policies, such as support to education and competition in the domestic markets may, on the other hand, increase both the inflow of technology and the absorbtive capacity of domestic firms. Thus, from an investment policy perspective, prescriptions seem more effective than proscriptions. This is not only because individual host countries have limited possibilities to influence the 
multinationals in their choice of production location, but also because technology transfer via MNCs depends, to a large extent, on the performance of the host country firms.

Foreign technologies may, of course, be acquired in other ways than foreign direct investment. Multinationals may transfer technologies through a number of other arrangements, for instance, joint ventures, licensing, and technical service contracts. Technology may also cross international borders through trade. Empirical evidence suggest, however, that these different avenues of technology transfer should be seen as complements rather than substitutes. The type of technology seems to influence the mode of transfer and certain advanced technologies are simply not available through other means than foreign direct investment. Thus, keeping the doors open for the acquisition of technical information through various channels will eventually lead to more technology transfer and higher productivity growth.

Another issue, which is indirectly related to the spillover question, has to do with the economic benefits of R\&D. Several studies have shown that the fruits of R\&D are transferable across international borders within firms and that they can be realized in other geographic locations than where the $R \& D$ activity was originally undertaken. Thus, subsidising research and development in multinational firms (foreign or domestic) does not guarantee benefits to the nation providing the subsidy if 
the economic environment at large is not favorable.

In sum, there is strong evidence that multinational firms have contributed to a geographical diffusion of technology and that active host countries can get access to modern technology via foreign direct investment. With the increasing global interdependence in the economic and technological spheres it can also be expected that multinationals will remain an important vehicle in the international diffusion of technology. 


\section{NOTES}

1. Cantwell's model is interesting in the sence that it stresses the importance of the relative technological capacity of the sector in the host country in analyzing the effects of foreign. investment. I find it troublesome, however, that this technological competence in a way is given from the beginning in his analysis, because that makes his model rather

"deterministic". How can his static model, for instance, explain the success of Japanese firms on the world market? or the emergence and success of Newly Industrializing Countries? An alternative, dynamic approach is given in Blomström and wang (1989), discussed below.

2. Although there are no statistical analyses of foreign investment and inter-industry spillovers, there are several studies of technological or R\&D spillovers between industries. The work of Bernstein is particularly relevant (see e.g. Bernstein 1988, 1989, and his chapter in this volume). See also Terleckyj (1980), Scherer (1982), Jaffe (1986), Wolff and Nadiri (1987), Bernstein and Nadiri (1989), and Mohnen (1990). 


\section{REFERENCES}

Balasubramanyam, U. N., International Transfer of Technology to India. New York, Praeger, 1973.

Behrman, $J$. and $H$. Wallender, Transfer of Manufacturing Technology within Multinational Enterprises. Cambridge, Mass., Ballinger, 1976.

Bernstein, J. I., "Cost of Production, Intra- and Interindustry R\&D Spillovers: Canadian Evidence." Canadian Journal of Economics, 21 (2), 1988.

Bernstein, J. I., "The structure of Canadian Interindustry R\&D Spillovers, and the Rates of Return to R\&D." Journal of Industrial Economics, 37 (3), 1989.

Bernstein, J. I. and M. I. Nadiri, "Research and Development and Intraindustry Spillovers: An Empirical Application of Dynamic Duality." Review of Economic Studies, $56,1989$.

Blomstrom, M., "Foreign Investment and Productive Efficiency: The Case of Mexico." Journal of Industrial Economics, 15 (1), 1986.

Blomström, M., Foreign Investment and Spillovers: A study of Technology Transfer to Mexico. London, Routledge, 1989 .

Blomström, M. and R.E. Lipsey, "The Export Performance of U.S. and Swedish Multinationals." Review of Income and Wealth, 35 (3), 1989.

Blomström, M., R.E. Lipsey and L. Ohlsson, Economic Relations between the United States and Sweden. New York and Stockholm, Svenska Handelsbanken, 1989.

Blomström, M. and P. Meller, Eds., Diverging Paths. Comparing a Century of Scandinavian and Latin American Economic Development. Baltimore, Johns Hopkins, 1991.

Blomstrom, $M$. and $H$. Persson, "Foreign Investment and Spillover Efficiency in an Underdeveloped Economy: Evidence from the Mexican Manufacturing Industry." World Development, $11(6), 1983$. 
Blomström, M. and $Y$. Wang, "Foreign Investment and Technology Transfer: A Simple Model." NBER Working Paper No. 2958, May, 1989.

Blomström, M. and E. Wolff, "Multinational Corporations and Productivity Convergence in Mexico." NBER Working Paper No. 3141 , October, 1989 .

Blomström, M. and M. Zejan, "Why Do Multinational Firms Seek Out Joint Ventures?" Journal of International Development, 3 (1), 1991 .

Brash, D.T., American Investment in Australian Industry. Cambridge, Mass., Harvard University Press, 1966.

Buckley, P.J. and P. Artisien, North-South Direct Investment in the European Communities. Iondon, Macmillan, 1987.

Cantwell, J., Technological Innovation and Multinational Corporations. Oxford, Basil Blackwell, 1989.

Caves, R.E., "Multinational Firms, competition, and Productivity in Host-Country Markets." Economica, 41, 1974.

Caves, R.E., Multinational Enterprise and Economic Analysis. Cambridge, Cambridge University Press, 1982.

Chen, E.K.Y., Multinational corporations, Technology and Employment. London, Macmilian, 1983.

Cortes, M. and P. Bocock, North-South Technology Transfer. A Case study of Petrochemicals in Latin America. Baltimore, Johns Hopkins, 1984 .

Dahlman, C.J., B. Ross-Larsen, and I.E. Westphal, "Managing Technological Development: Lessons from the Newly Industrializing Countries." World Development, 15 (6), 1987.

Davidson, W.H., Experience Effects in International Investment and Technology Transfer. Ann Arbor, Mich., UMI Research Press, 1980.

Deane, R.S., Foreign Investment in New Zealand Manufacturing. Wellington, Sweet \& Maxwell, 1970.

Dunning, J., American Investment in British Manufacturing Industry. London, George Allen \& Unwin, 1958. 
Dunning, J., "Multinational Enterprises, Market structure, Economic Power and Industrial Policy." Journal of World Trade Law, 8, 1974.

Eliasson, G., et al, De Svenska storföretagen. (Large Swedish Companies), Stockholm, Industriens Utredningsinstitut, 1985.

Forsyth, D., U.S. Investment in Scotland. New York, Praeger, 1972.

Gabriel, P.P., The International Transfer of Corporate Skills: Manaqer contracts in Less Developed Ccuntries. Cambridge, Mass., Harvard University Press, 1967.

Germidis, D., Ed., Transfer of Technology by Multinational Corporations. Volume 1. Paris, OECD, 1977.

Gershenberg, I., "The Training and Spread of Manegerial Know-How. A Comparative Analysis of Multinational and other Firms in Kenya." World Development, 15 (7), 1987.

Globerman, S., "Foreign Direct Investment and "Spillover" Efficiency Benefits in Canadian Manufacturing Industries." Canadian Journal of Economics, 12 (1), 1979.

Gorecki, P.K., "The Determinants of Entry by Domestic and Foreign Enterprises in Canadian Manufacturing Industries: Some Comments and Empirical Results." Review of Economics and Statistics, 58 (4), 1976.

Grosse, R., Multinationals in Latin America. London, Routledge, 1989.

Jaffe, A. B., "Technology opportunity and Spillovers of R\&D: Evidence from Firms' Patents, Profits, and Market Value." American Economic Review, 76, 1986.

Katz, J.M., Ed., Technoloqy Generation in Lat in American Manufacturing Industries. New York, St. Martins Press, 1987.

Knickerbocker, F.T., "Market structure and Market Power Consequences of Foreign Direct Investment by Multinational Companies." Occasional Paper No. 8, Washington, DC., Center for Multinational studies, 1976. 
Kokko, A., "Host Country Competition and Technology Transfer by U.S. Multinationals." Mimeo, Stockholm School of Economics, 1990.

Lake, A. W., "Technology creation and Technology Transfer by Multinational Firms." in R.G. Hawkins, Ed., Research in International Business and Finance. Vol. 1. Greenwich, CT., JAI Press, 1979.

La11, S., "Vertical Inter-Firm Linkages in LDCs: An Empirical 'study." Oxford Bulletin of Economics and Statistics, 42 (3), 1980 .

Lim, L. and P.E. Fong, "Vertical Linkages and Multinational Enterprises in Developing Countries." World Development, 10 (7), 1982 .

Lipsey, R.E., The Impact of Service TNCs on Developing Countries. New York, UNCTC, 1990.

Lipsey, R.E. and I.B. Kravis, "The competitive Position of U.S. Manufacturing Firms." Banca Nazionale del Lavoro Quarterly Review, 153, 1985.

Mansfield, E. and Associates, Technoloqy Transfer, Productivity, and Economic Policy. New York, Norton, 1982.

Mansfield, E, and A. Romeo, "Technology Transfer to Overseas Subsidiaries by Us-based Firms." Quarterly Journal of Economics, 95, 1980 .

MCAleese, D. and D. MCDonald, "Employment Growth and Developmnent of Linkages in Foreign-Owned and Domestic Manufacturing Enterprises." oxford Bulletin of Economics and Statistics, 40,1978 .

McFetridge, D.G., "The Timing, Mode and Terms of Technology Transfer: Some Recent Findings" in A.E. Safarian and G.Y. Bertin, Eds., Multinationals, Governments and International Technology Transfer. London, Croom Helm, 1987.

Mohnen, P., "The Impact of Foreign R\&D on Canadian Manufacturing Total Factor Productivity Growth." University of Montreal, CERPE Working Paper 58, July, 1990.

OECD, OECD Science and Technology Indicators. No. 2, R\&D, Invention and Competitiveness. Paris, OECD, 1986.

OECD, New Technoloqies in the 1990s. A Socio-economic strategy. Paris, OECD, 1988. 
OECD, Technology and Global Competition. Paris, OECD Development Center, 1989.

Reuber, G., et al., Private Foreign Investment in Development. oxford, Clarendon Press, 1973.

Rosenbluth, G., "The Relation Between Foreign Control and Concentration in Canadian Industry." Canadian Journal of Economics, 3 (1), 1970.

Safarian, A.E., Foreign Ownership of Canadian Industry. Toronto, McGraw-Hill, 1966.

Scherer, F.M., "Interindustry Technology Flows and Productivity Growth." Review of Economics and Statistics, 64,1982 .

Shelp, R.K., et. al, Service Industries and Economic Development. New York, Praeger, 1984.

Swedenborg, B., Den svenska industrins utlandsinvesteringar 1960-1986. (Swedish Investment Abroad 1960-1986), Stockholm, Industriens Utredningsinstitut, 1988.

Teece, D., The Multinational Corporation and the Resource cost of International Technology Transfer. Cambridge, Mass., Ballinger, 1976.

Terleckyj, N. W., "Direct and Indirect Effects of Industrial Research and Development on the Productivity Growth of Industries." in J. W. Kendrick and B. Vaccara, Eds., New Developments in Productivity Measurement. New York, National Bureau of Economic Research, 1980.

Wolff, E. N. and M.I. Nadiri, "Spillover Effects, Linkage structure, Technical Change, and Research and Development." Draft, New York University, 1986.

Yoshihara, K., The Rise of Ersatz Capitalism in South-East Asia. oxford, oxford University Press, 1988.

Zejan, M., "R\&D Activities in Affiliates of Swedish MNEs." Scandinavian Journal of Economics, 92 (3), 1990. 
Figure 1. R\&D expenditure in the business enterprise sector

As a percent of value added

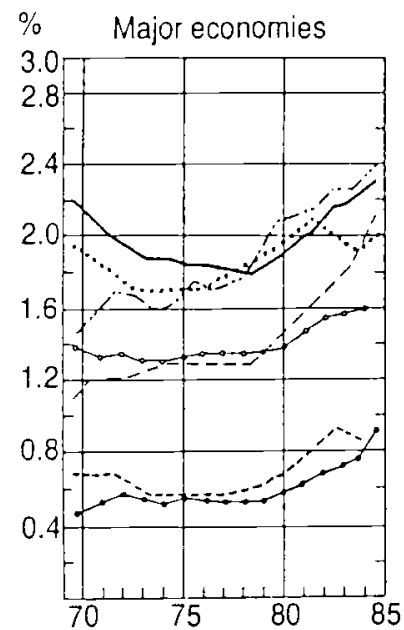

$\% \quad$ Small economies
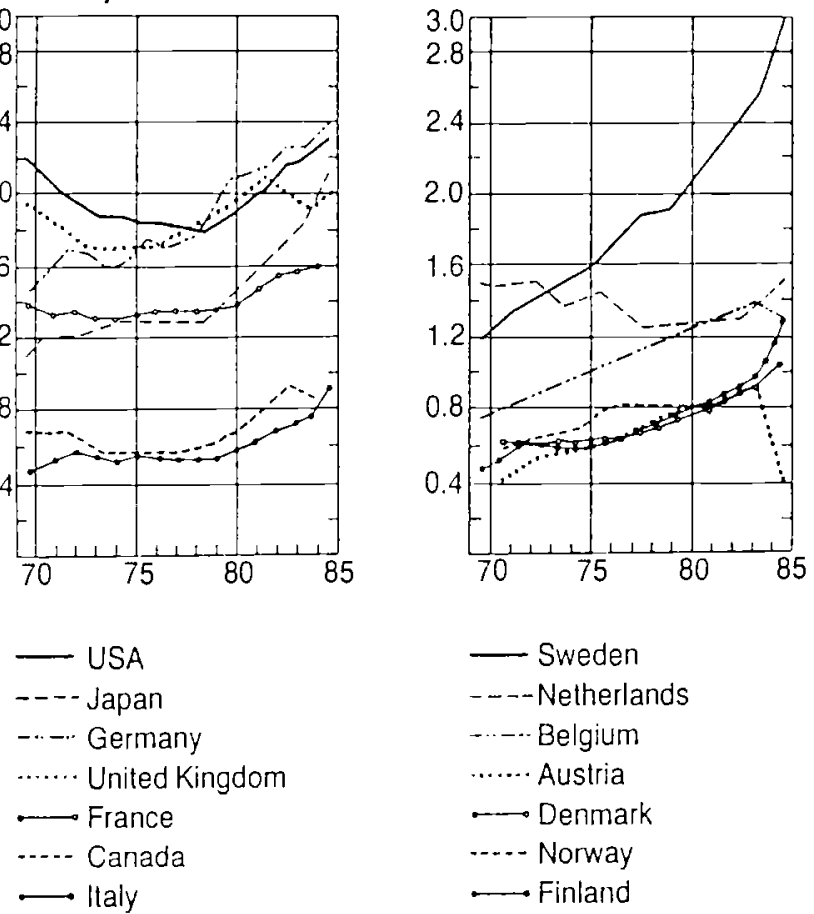

Source: OECD 1986 
Figure 2.। Global revealed comparative advantages of Sweden 1970-85
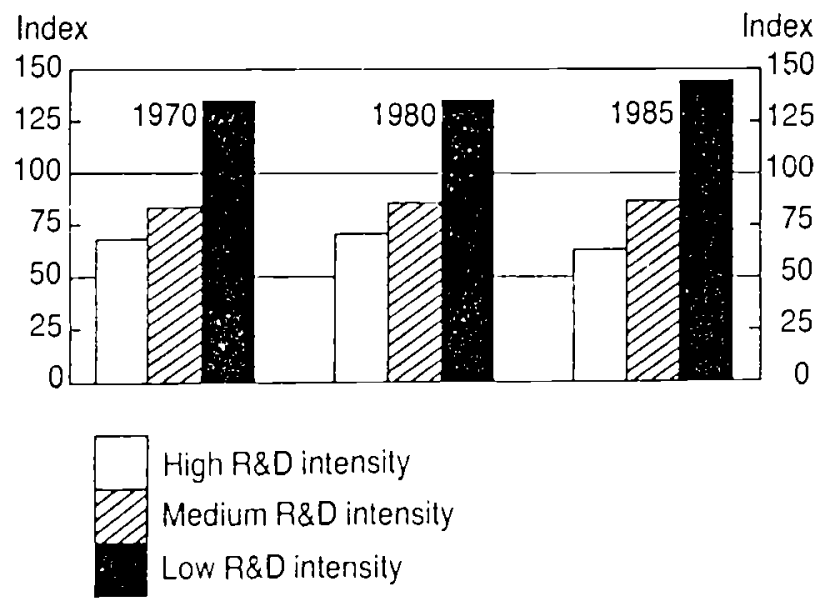

- Revealed comparative advantages are for a sector defined as the ratio between the country's sectoral share of OECD exports and its overall export share.

Source: Blomström, Lipsey and Ohısson, 1989 